\title{
SYRIAC INSCRIPTIONS FROM A MELKITE MONASTERY ON THE MIDDLE EUPHRATES
}

\author{
By Erica C. D. Hunter
}

(PLATES I-IV)

During a survey of the Djebel Khaled area, in conjunction with the excavation of the nearby Bronze Age site of El Qitar, Professor Graeme Clarke discovered two Syriac inscriptions on the wall of a small, vaulted tombchamber. Tracings were made and these, together with photographs of both the inscriptions and the sepulchre, were sent to me so that I might translate their contents and offer accompanying comments. In the meantime, Professor Clarke has published his valuable description of the Djebel Khaled area and its necropolis, including the tomb-chamber. ${ }^{1}$ Furthermore, Professor Takamitsu Muraoka has offered a tentative reading of the two Syriac inscriptions. ${ }^{2}$

This paper intends to provide translations of both the inscriptions, whose state of preservation can at best be described as deteriorated. Mindful of this, I have devoted considerable attention to the palaeographic notes accompanying the translations, before examining the palaeographic styles of the two Syriac inscriptions. Consequently, I shall attempt to date the inscriptions, which have been written by different hands, taking into account variations which might be considered as chirographical. ${ }^{3}$ However, in the absence of any other means, palaeographic studies remain the only choice that is available.

The second part of this paper provides a discussion of the inscriptions' functions. Of course, one cannot suppose that they were united by the same purpose, nor can they be automatically linked with the suggested re-use of the Roman tomb-chamber for a later Christian burial. ${ }^{4}$ But, by considering the contents of the two inscriptions, one can place them in the context of the sepulchre in which they were found, and within a wider milieu, for the chronological information which they impart permits a contribution to our knowledge of Syriac Christianity in northern Syria.

\section{Physical description of inscriptions I and II}

The upper inscription which will be designated as Inscription I, consists of five lines and is separated from the lower inscription by a distance of approximately $10 \mathrm{~cm} .{ }^{5}$ The latter, which will be designated as Inscription II, consists of eight lines. At first glance one can tell that they are the products of different hands and were not incised, but were inscribed either in charcoal or in an ink with a lampblack base. ${ }^{6}$ The inscriptions were written on a soft and

\footnotetext{
' G. W. Clarke, 'Syriac inscriptions from the Middle Euphrates ', Abr Nahrein, xxIII, 1984-85, 73-82. The author wishes to thank Professor Clarke for sending her the photographs of the inscriptions and other information pertaining thereto, the Rev. Professor John Emerton for the assistance which he has given her in the preparation of this paper, and Dr. Andrew Palmer for preliminary suggestions.

${ }^{2}$ T. Muraoka, 'Two Syriac inscriptions from the Middle Euphrates', Abr Nahrein, xxil, 1984-85, 83-9.

${ }^{3}$ J. A. Montgomery, Aramaic incantation texts from Nippur (Philadelphia, 1913), 27-8, discusses the shortcomings of using palaeography as a dating method and emphasizes the role of scribal idiosyncrasy in the execution of scripts.

${ }^{4}$ Clarke, op. cit., 79 , cites the usage of crosses over the entrance of the tomb-chamber and over the actual tomb itself to support the proposed Christian burial. See plate I $(a)$.

${ }^{5}$ This measurement was given in private correspondence between Clarke and Hunter (24 September 1986), although the actual distance between the two inscriptions does not seem to have been recorded.

${ }^{6}$ W. H. P. Hatch, An album of dated Syriac manuscripts (Boston, 1946), 11, notes that the Syrians made an ink out of lampblack mixed with oil or gum.
} 
porous limestone whose weathering is probably the cause of numerous lacunae which occur in both Inscriptions $I$ and $I I{ }^{?}$

Inscription I occurs at the very extremity of the wall over the tomb, with the first line following the now uneven edge of the arch. ${ }^{8}$ Since the points of the upward strokes of 1 . 1 seem to terminate abruptly and the latter part of this line has all but disappeared, it would appear that physical deterioration or erosion has taken place after the writing of the inscription. One might be tempted to suggest that the commencement of Inscription I has also disappeared, but the faint paragraphus to the right of the first letter would seem to indicate otherwise. Elsewhere the inscription has been damaged to such an extent that only 11.2 and 5 can be confidently read.

The overall appearance of Inscription $I$ is, however, one of relative neatness. The initial letters of the five lines form an even right-hand margin, with only the oblique stroke of the initial Alaph in 1.3 breaking it. The left-hand margin that is formed by $11.2-5$, since 1.1 has been eroded, also seems to be even and is interrupted only by the extension of 1.4. Finally, the spacing between 11. 2-3, 11. 3-4 and 11. 4-5 appears to be regular, with each line being separated by approximately $2 \mathrm{~cm} .{ }^{9}$ Only the spacing between $11.1-2$ differs, being $1.5 \mathrm{~cm}$. and thus producing a more cramped aspect.

Although Inscription II is found on the same surface as Inscription I, it occurs deeper within the vaulted tomb-chamber. Yet it has deteriorated to a much greater degree, so much so that the left-hand side of this inscription is illegible, except for sporadic letters. And the remainder of Inscription $I I$ is at best only semi-legible. To compound the difficulties, a graffito of either three or four upper case letters has been scratched across the inscription, thus obliterating part of the already faint text. The graffito seems to be unrelated to Inscription II and probably was executed in relatively recent times. ${ }^{10}$

The physical appearance of Inscription II presents a marked contrast to Inscription I. The right-hand margin is roughly straight, but there appears to have been no attempt by the scribe to create a left-hand margin. Furthermore, the lengths of the lines vary considerably, with disparity being evident between 1.4 and 1.7 , whose lengths are 30 and $20.5 \mathrm{~cm}$. respectively. The spacing between the lines is similarly irregular, with the pronounced hiatus between 11.6-7 suggesting the possibility of an intermediate line. ${ }^{11}$ The lines also tend to conclude with an upward slant, particularly in the latter half of the inscription.

Both Inscriptions $I$ and $I I$ seem to have been written freehand, nevertheless Inscription I does maintain an impression of regularity in comparison to Inscription II; probably because it is more spacious. The width of Inscription I at its right-hand margin is $14.5 \mathrm{~cm}$., whilst the dimensions of Inscription $I I$ are, interestingly, only marginally more, at $15.75 \mathrm{~cm}$. Similarly, the length of line in Inscription II is only slightly longer than in Inscription I, but appears to accommodate double the number of characters. ${ }^{12}$ Although the script of

\footnotetext{
${ }^{7}$ The extent of the weathering is difficult to determine. In private correspondence (14 June 1984) Clarke suggested to Hunter that the tomb-chamber had been recently opened by villagers, resulting in some deterioration.

${ }^{8}$ See plate I $(b)$.

${ }^{9}$ In the absence of measurements being recorded in situ, the tracings of the inscriptions were placed over a grid and the results were recorded.

${ }^{10}$ Clarke in private correspondence with Hunter (24 September 1986) thinks that a local lad tried to write his name AHM. . in 'English' script or may have made an attempt to commence the alphabet.

"Muraoka, op. cit., 88, is convinced that a line exists, thus making Inscription II nine lines in total. We fail, however, to detect any traces of an intermediate line, so that the sum stands at eight.

${ }_{12}$ An exact estimate cannot be made, due to the deteriorated state of Inscription II, where no single complete line remains.
} 
Inscription $I I$ is smaller than that of Inscription $I$, the former has a more untidy appearance.

\section{Inscription $I^{13}$}
1. KLHWN H( Y)L $\mathrm{L}^{9} \mathrm{YK}_{\mathrm{R}}$.
2. WBŠMH DMR
3. '.S̊YP' 'WN
4. MRY' $M^{\prime}(D) R \ldots$ L'
5. 'BDYN LY BYS''

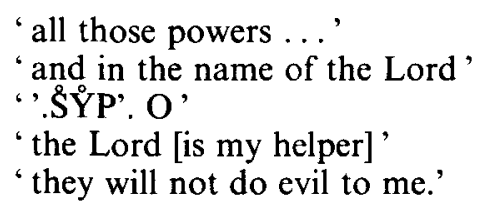

\section{Palaeographic notes}

1. 1: KLHWN is a mixture of majuscule and minuscule letters. ${ }^{14}$ The initial Kaph is majuscule and is ligatured to the Lamadh whose full extent in unknown since the upper stroke terminates abruptly at the edge of the arch. The Lamadh is ligatured to the He which is minuscule, even though the bottom left of the circle has deteriorated. Similarly the Waw is cursive, with the closed circular form of the minuscule style. The final, unattached Nun has a definite wedgeshaped head that tapers into a downward stroke.

$\mathrm{H}(\mathrm{Y}) \mathrm{L}^{9}$ is largely reconstructed since the only legible letter is the Lamadh which once again appears to have been abruptly terminated by the erosion of the arch's edge. The initial Heth is suggested by the curvature of the opening stroke, although the remainder of this letter as well as the following Yodh have been obliterated. The final Alaph is read on the basis of the letter's spacing and from the very faint traces of an upward stroke as well as a tail. The reading $\stackrel{\mathrm{H}}{\mathrm{L}}(\mathrm{Y}) \mathrm{L}^{9}$ is further supported by the Seyame which occurs to the right of the Lamadh. ${ }^{15}$

YKR . $^{9}$ commences with a Yodh and the third letter, Resh, exhibits a clear wedge-shaped head on a curved form that suggests a cursive style. The second letter, which is ligatured to the preceding Yodh, would seem from the slant of its upward stroke to be a Kaph. It could possibly be a Waw, but the open shape of this letter and its possible ligature to the following Resh would argue against this interpretation. ${ }^{16}$ Only traces of the beginning of the fourth letter remain and from the angle of the vertical and base lines, it could be interpreted as either Beth, Qoph, Mim or Nun. Which possibility might apply is impossible to determine owing to the deterioration that has almost obliterated the rest of the word. A final Alaph might be suggested from the juncture of the base line and an upward oblique stroke, albeit this is extremely faint. Such is the state of the inscription that one cannot discern whether an intermediate letter might occur

${ }^{13}$ See plates II and IV $(a)$.

${ }^{14}$ The terms majuscule and minuscule first appear to have been used by J. P. N. Land, Symbolae Syriacae (Lugdano-Batavae, 1862) and were adopted by Enno Littmann, Syria: Publications of the Princeton University Archaeological Expeditions to Syria in 1904-5 and 1909. Division IV. Semitic Inscriptions (Leiden, 1934), p.x. He notes that Land's majuscule script was about the same as Estrangela and his minuscule script was similar to Serta. Hence we have elected to use the terms majuscule and minuscule respectively to indicate a script with formal characteristics, showing an affinity with Estrangela and a script with cursive tendencies suggestive of Serta. Whilst Land coined the terms in respect to manuscript material, Littmann's publication concerned incised inscriptions, and therefore would be somewhat appropriate to Inscriptions $I$ and $I I$.

${ }^{15}$ Muraoka, op. cit., 83, reads SL. . . thereby interpreting the opening stroke as that of Shin and the Seyame as the upper points of an open, unfilled Shin; an example of which is found in 1.2 . If the letter were read as such, the spacing between the dots would suggest that it was cramped. The interpretation of the two dots as Seyame is, of course, supported by the preceding word KLHWN which would be accompanied by a plural, masculine substantive.

${ }^{16} \mathrm{Hatch}$, op. cit., plate CXXII, provides several examples of a Waw introduced by an oblique stroke that turns into a short, vertical stroke connected to the base line to form a closed character Furthermore, in contrast to the common practice, Waw appears to be ligatured on several occasions to the consecutive Taw. 
between the fourth and final letters. The spacing could accommodate another letter, but on the other hand the final Alaph could have assumed an elongated form as is commonly encountered. ${ }^{17}$

1. 2: WBŠMH shows a mixed hand with the initial Waw and the final He exhibiting the closed, cursive forms of minuscule, whilst the Beth, Shin and Mim have the angular lines of the majuscule type. ${ }^{18}$ With the exception of the initial Waw, all the letters are ligatured.

DMRY' 'commences with a Dalath that is marked by a clear diacritical point below the letter. The second letter, Mim, reproduces the majuscule form of the previous word. Although the short, vertical stroke of the third letter does not reproduce the curved Resh of 1.1 , the diacritical point distinguishes it as such. The word concludes with a definite example of an Alaph, but the spacing between it and the Resh is problematical for it could be sufficient for another letter and the traces of a vertical stroke midway between the Resh and the Alaph could suggest a Yodh. ${ }^{19}$ On the other hand, an extended base line may have lead into the final Alaph as is often found, especially in manuscripts.

1. 3: '.S̊Y Y $P$ ' is the reading established for this enigmatic word. The clear, initial Alaph is majuscule, but appears to have been tempered by a scribal idiosyncrasy since the base line is joined directly to the oblique upward stroke, unlike the immediately preceding letter. Similarly, the final Alaph shows a third variant on the letter, as may be seen by the angle of the oblique line and its juncture with the base line. The penultimate $\mathrm{Pe}$ is ligatured to both the following Alaph and the preceding letter which is problematic. Several possibilities could occur in the spacing between the initial Alaph and the Pe. The combination ZQY may be fleetingly entertained, but the Zain cannot be supported palaeographically. ${ }^{20}$ The second possibility may be read WSß; however, there is some difficulty in the disparity of the loops of the Semkath. ${ }^{21}$ Also the Waw is problematic and seems unlikely in the light of the minuscule examples which occur in 11.1 and 2. The third possibility, .SY, seems more feasible since it is common for the right-hand loop of Semkath to be smaller than the left-hand one. The introductory stroke suggests that a letter might occur between the Alaph and the Semkath and the spacing would support this conclusion. ${ }^{22}$ The Yodh following Semkath may be deciphered with little difficulty.

'WN commences with Alaph as is established from the definite base line and the upward oblique stroke. The projection to the left of the junction between these two lines could be part of the Alaph, thus producing a unique form. Alternatively, it could be the head of either a Dalath or a Resh with the stem being provided by the lower part of what is read as the oblique line of the Alaph

\footnotetext{
${ }^{17}$ Muraoka, op. cit., 83, reads YKRW..., but the angularity of the fourth letter would argue against it being a Waw, as the letters in KLHWN and on 1. 2 WBSMH indicate a cursive trend.

${ }_{18} \mathrm{ibid} ., 84$, suggests that the top horizontal bar of the Shin should be restored, on account of the letter's form in 1. 5 . Both the open and closed forms of Shin do occur in inscriptions as seen in Littmann, op. cit., Inscription 42 from Dēr Sim'ān and Inscription 52 from Kefr Nābu, both of which date from the sixth century A.D.

${ }_{19}$ ibid., 83, sees two letters between the Resh and the final Alaph, hence producing the reading MRYM'. On the grounds of space, it would seem difficult to accommodate a penultimate Mim, given the size of the two examples which occur in 1.2.

${ }^{20}$ idem reads '.ZQYP', but on p. 85 he states that the 'excessive space between the initial Alef and the Qof ... would speak against such an interpretation.' Furthermore, Zain always seems to be written as a short, vertical stroke and it is difficult to visualize the elongated, horizontal stroke leading into the open curved form as this letter.

${ }^{21}$ A survey of manuscripts in Hatch, op. cit., and inscriptions in Littmann, op. cit. and $\mathbf{H}$. Pognon, Inscriptions sémitiques de la Syrie, de la Mésopotamie et de la région de Mossoul (Paris, 1907), does not indicate that the right-hand loop of the Semkath was written larger than the lefthand loop, as would be the case here.

${ }^{22}$ The difficulty with this interpretation is that the above survey also establishes that the connecting stroke joins the letter Semkath at its base line and not at the top of the right-hand loop.
} 
which would abruptly terminate. Given the three previous examples of Alaph in 11. 1-3 of the inscription, which favour a majuscule style, we suggest that the letter be interpreted similarly. Reading the second letter is also problematic, for it could be either a cursive Waw or a Yodh. The former is preferred, in the light of the minuscule example on 1.1 even though the letter appears to be ligatured to the preceding Alaph. An unattached Nun, whose wedge-shaped head tapers into a pronounced downward stroke, concludes. ${ }^{23}$

1. 4: MRY' commences with a clearly legible Mim which is written in the majuscule style and is ligatured to the second letter, Resh, whose diacritical point is just visible. Only traces of the Yodh remain; the uppermost point of the vertical stroke and the base line joining this letter with the final Alaph, whose form is majuscule.

M'(D)R also commences with a Mim, notable because it does not feature the upward oblique stroke of the three previous examples which occur in this inscription. Instead, the upper stroke continues horizontally ending in a slight upward flourish. The Mim is ligatured to the 'E, but at this point the word has deteriorated. The third letter has been entirely obliterated, but it may be Dalath. The following letter is suggested, on the reading of its diacritical point, to be Resh. ${ }^{24}$

L' exhibits a clear, final Alaph whose style is more cursive than in the previous examples of this letter. The commencing letter is ligatured to the Alaph and is read as a Lamadh, even though only the lower part of the upright stroke is visible. ${ }^{25}$

1. 5: 'BDYN has a clear, initial ' $E$ which is distinguished from the example in 1.4 by its curved stroke. Similarly, the following Beth differs from the preceding examples which are majuscule. The third letter, Dalath, is indicated by its lower diacritical point. The penultimate Yodh and the final Nun are distinct and uphold the cursive aspect of the first two letters of this word. ${ }^{26}$

LY provides us with a fine example of Lamadh that is ligatured to a final Yodh.

BYS' supplies a second example of a Beth with cursive tendencies. The following Yodh is undistinguished, but provides the third form of this letter in the one line. By contrast, the penultimate letter, Shin, is noteworthy since it differs in both style and size from the example in 1.2. Not only is it at least a centimetre larger, but the two oblique sides are joined by an upper, horizontal stroke. In fact, its decidedly majuscule style contrasts with the cursive tendencies which we have pointed out in this line and which are found in the final Alaph that concludes both this word and the inscription.

\section{Palaeographic summary}

Littmann's comments in reference to an inscription at Kefr Lāb, dated

\footnotetext{
${ }^{23}$ Muraoka, op. cit., 83, reads . Y Y, by which he has interpreted the initial Alaph as two letters, albeit undeciphered. Although the penultimate letter could be a Yodh, the clear example of a Yodh ligatured to the following Nun in 1.5 , acts contrary to this reading.

${ }^{24}$ idem similarly reads $M$.. and comments on p. 85, "we first thought we could see M'DR "helper", but so little is left visible of the latter half.' Muraoka may, therefore, lend cautious support to our suggestion.

${ }^{25}$ idem interprets these two letters as $\mathbf{N}$, concluding the word $\mathrm{M}$. . . N'. Whilst our reading does differ, agreement has been reached on the final Alaph. I have not been able to decipher the first letter which Muraoka has read as a Mim. Nor would I specify how many letters occur before the penultimate character; on the grounds of spacing, three or four might be written. Nor would I specify what word division might occur as several options could apply. $M^{\prime}(D) R(N Y$ ') L' could be proposed or one could even suggest $M^{\prime}(D) R$ (S'D') L'. Both readings would be satisfactory in a contextual sense.

${ }^{26}$ ibid., 85 , is " slightly concerned about the gap between the end of the base line of the Beth and the Dalath' in 'BDYN. There does not seem to be any suggestion of 'BYDYN which Muraoka quite promptly rejects and the slightly irregular spacing may be attributed to scribal idiosyncrasy.
} 
A.D. 771-772, ' [i]t is an admixture of majuscule and minuscule forms', may well apply to Inscription $I .{ }^{27}$ It accommodates a cursive trend within the 'stiffer, more angular' aspect of its palaeography. ${ }^{28}$ Hence the Mim is closed according to the Serta style, but its form displays a squareness that is reminiscent of the Estrangela script. ${ }^{29}$ Similarly, the letters Resh and Dalath are cursive, but have not developed the reversed $C$ shape that is commonly associated with Serta. ${ }^{30}$ Other letters, such as He and Waw are, on the other hand, to be placed within the Serta tradition. ${ }^{31}$

The palaeography of Inscription $I$ appears to have been undergoing a transition from a more formal to a more cursive script. This trend may be especially seen in the six examples of the letter Alaph that occur in the inscription. Indeed, three different styles of Alaph may be discerned; ranging from the majuscule where the base and oblique lines are connected by a short upward stroke to the semi-majuscule where the oblique stroke ends in a nodule and connects directly with the base line. ${ }^{32}$ The third type, consisting of a simple interception between the base line and the upward stroke is minuscule. ${ }^{33}$

Similarly, in the case of the letter Beth, two styles of script may be detected. An angular, majuscule example occurs in 1.2, whereas two cursive characters may be found in 1. 5. We may ask whether the promiscuity of form which has been shown by several letters, notably Alaph, Beth and Mim, is sufficient indication that the palaeography of Inscription I was transitional. Rather, the tendency towards Serta letters in the latter part of the inscription could suggest that the writer commenced using his 'best' hand but, as happens so often,

${ }^{27}$ Littmann, op. cit., 41 .

${ }^{28}$ Hatch, op. cit., 24, discusses the role of the medium in the production of scripts and in doing so distinguishes between epigraphy and palaeography. In adhering to his distinction, the latter term has been used in connexion with Inscriptions $I$ and $I I$ since they have been painted or written, rather than incised, on the rock medium.

${ }^{29}$ Muraoka, op. cit., 84 , comments that the letter Mim, which is closed, shows interesting variations on the upper oblique stroke-ranging from the almost horizontal example to those slanting in different degrees. As such, he proposes that the letter represents an intermediate stage between classic Estrangela and classic Serta. Whilst I agree with this finding, I would also point out the similarity of the letter to several specimens in inscriptions from the thirteenth century A.D. See Littmann, op. cit., Inscription 28 from Dēr Sim'ān and H. Pognon, op. cit., Inscription 94 (plate XXXVIII) from the Convent of St. Abai near Mardin. The form of the letter where the upper oblique stroke proceeds from the top left to the top right instead of descending to the base line, is also found in a Melkite manuscript from the thirteenth century A.D. See Hatch, op. cit., plate CLXXIII.

${ }^{30} \mathrm{ibid}$., 83, claims that the letter Resh in the inscription has a ' shape of a reversed C'. We would describe the forms of both the letters Dalath and Resh as being intermediate between the Serta and the angular shape of Estrangela. See Pognon, op. cit., Inscription 94 (plate XXXVIII).

31 ibid., 84, notes that the He departs from the classical Estrangela form and approaches the classic Nestorian style of two left-hand downward strokes joined to form a circle. The closed form of $\mathrm{He}$, with a straight connecting stroke and stem is found frequently in inscriptions; appearing as early as A.D. 491 at Bāṣufān. See Littmann, op. cit., 39. Apart from occurring in Estrangela and Nestorian manuscripts, the He can be seen in a Melkite manuscript from A.D. 1045. See Hatch, op. cit., plate CLXXXIV.

${ }^{32}$ The Alaph at the end of 1.2 is the only definite example of the majuscule type, although the first letter of the second word in 1.3 could be also. The semi-majuscule type is represented by the initial Alaph in 1.3 and the first Alaph in 1.4 and its cursive trend would appear to uphold the transitional characteristic of the inscription's palaeography. The two types of Alaph are found in the thirteenth century inscription from the Convent of St. Abai, near Mardin. See Pognon, op. cit., Inscription 94. The semi-majuscule Alaph first appears in a Nestorian MS from A.D. 719-20, but it also frequently occurs in the Estrangela script; with the earliest example dating from A.D. 740. See Hatch, op. cit., plates CLXII and LXXIV and also plate CLXXXIV, being a Melkite manuscript from A.D. 1045 wherein the semi-majuscule and minuscule types are written.

${ }^{33}$ Like Muraoka, op. cit., 85, we would group together the two Alaphs at the end of 11.4 and 5 respectively, noting that they are the product of a single stroke, rather than two. We have termed these characters minuscule and they appear to belong to the Serta tradition, and together with the majuscule and semi-majuscule types appear in a Serta manuscript dated from A.D. 1056. See Hatch, op. cit., plate CXXII. Finally, three forms of Alaph are also found in a graffito from Dēr Sim'ān in northern Syria. See Littmann, op. cit., Inscription 32. 
lapsed. ${ }^{34}$ Furthermore, many of the minor variations in form may be chirographical.

The majuscule qualities of what is essentially a minuscule script may have resulted from an attempt to simulate an incised inscription. Such a motive might explain the form of the letter Shin, which appears twice as an inverted, unfilled triangle; albeit on one occasion minus the upper horizontal stroke. Despite this inconsistency, the Shin indicates a contact or familiarity with epigraphic scripts, for both the complete and incomplete types frequently occur in inscriptions. ${ }^{35}$ Indeed, this form of Shin is almost unattested in manuscripts, thereby suggesting that its usage was restricted. ${ }^{36}$

The combination of both minuscule and majuscule elements in Inscription I, leads us to describe the scribe's hand as being mixed. Hence one may classify the palaeography as being an Estrangela 'that is not of the purest or the earliest type', or alternatively as a Serta which has been modified, possibly in an attempt to accommodate some epigraphic conventions. ${ }^{37}$ Which of these two designations is more appropriate for Inscription $I$ is difficult to decide, for, as Hatch reminds us, 'sometimes in the same manuscript some letters have the Estrangela form and others are of the Serta style' ${ }^{38}$

The palaeography of Inscription I suggests that it could be Melkite, since this script bears a strong resemblance to Serta, yet is also in some respects akin to Estrangela. ${ }^{39}$ Thus the closed forms of $\mathrm{He}$ and Waw occur in Melkite, as in Inscription I and similarly the Mim is closed. Whilst the Serta form of Alaph was commonly used in the Melkite script, examples of the Estrangela type also occur as is the pattern of the letter in this inscription. Furthermore, the unfilled Shin is atypical of both the Serta and Estrangela scripts, but occurs in Palestinian Melkite manuscripts and in an inscription considered to be Melkite from the twelfth century A.D. ${ }^{40}$

Whilst the designation Melkite can be applied to Inscription I, albeit cautiously, we may be more definite about its dating. Muraoka proposes that it be placed within 'the early part of the second millennium' and during this period a tendency towards cursiveness appeared when the Estrangela script declined in usage-being countered by the rise of mixed hands that were strongly influenced by Serta. ${ }^{41}$ The palaeographic patterns of the inscription suggest, indeed, that it emanated from the twelfth-thirteenth century A.D.

\section{Commentary}

1. 1: KLHWN H(Y)L $L^{3}$ YKR.' 'all those powers ... . The semantics of YKRR.' are difficult to establish, but the word does appear to be an attributive

${ }^{34}$ Littmann, op. cit., 37, whilst commenting on the mixture of minuscule and majuscule letters in an inscription from Dèr Sim ân says that the repetition of this phenomenon, "shows that the men who carved inscriptions or graffiti endeavoured to use the majuscule script because of its monumental character, but were influenced by the minuscule script which was then in use for manuscripts.'

${ }^{35}$ Littmann, Semitic inscriptions (New York, 1904), 33, says that $\nabla$ may be considered as an intermediate stage between $\bigvee$ and the later form of Shin.

${ }^{36}$ Hatch, op. cit., Plates CXCVIII and CC, being Palestinian Melkite manuscripts written in A.D. 1030 and 1118 respectively. The examples cited by Muraoka, op. cit., 84, do exhibit a triangular shape, but otherwise bear little resemblance to the discussed Shin form since they are filled in.

${ }^{37} \mathrm{~J}$. Gwynn, The Apocalypse of St. John in a Syriac version hitherto unknown (Dublin, 1897), p. cxii, discusses the features of the script of later Estrangela. He particularly notes the closed forms of He, Waw and Mim as well as the curved, rather than rectangular shapes of Dalath and Resh.

${ }^{38}$ Hatch, op. cit., 30

${ }^{39}$ ibid., 28-9, outlines the distinguishing features of the Melkite script and provides notes on the individual characters in pp. 31-7.

${ }^{40} \mathrm{~J}$. B. Segal, 'Four Syriac inscriptions', Bulletin of the School of African and Oriental Studies, xxx, 1967, 302-4, discusses a grave inscription from Şuayip-şehri, near Edessa, and infers that it was erected by members of the Melkite church.

${ }^{41}$ Muraoka, op. cit., 85 . 
adjective. If the missing letter were read as a Qoph, the word could be $Y W R(Q)$ ' 'tender, greenish' and some suggestion of fertility or regeneration could be proposed ${ }^{42}$ If, on the other hand, the copyist had written a Kaph instead of a Qoph, and the missing letter were read as Yodh, the intended word would have been YKRY' 'glorious'. The connotation of 'all those (glorious) powers' would be particularly appropriate at the beginning of an inscription.

1. 2: WBSMH DMRY' ' and in the name of the Lord '. This phrase is linked to KLHWN H(Y)L $\mathrm{L}^{9} \mathrm{YKR}$.' by the Waw. In view of the usage of the preposition Beth with SMH DMRY', we may ask whether KLHWN should also bear a prefix. However, there is no palaeographic evidence to support this proposal.

1. 3: '.SYP' is enigmatic and could be a descriptive epithet in apposition to WBŠMH DMRY'. If the second letter is read as a Waw, the word could be derived from YSP, Aph'el 'WSP' to add, increase, do more '. ${ }^{43}$ The final Alaph could indicate a substantive, possibly meaning ' he who augments, increases', an interpretation which would be suitable especially if the final word on 1.1 was associated with fertility or vegetal powers.

On the other hand, it is tempting to suggest that '.SYP' is a proper name relating to WBŠMH DMRY'. The combination of Semkath and Pe calls to mind Josephus, but in spite of the variety of spellings of this name; viz YWSYP', YWSYPWS and YWSP, the initial and final Alaph are problematic. ${ }^{44}$ It may be possible that the Greek ending ios is rendered by an Alaph, even though such a pattern is considered to be unusual. ${ }^{45}$ Alternatively, the final Alaph could indicate an Aramaization of the name. ${ }^{46}$ If ' $S Y \mathrm{P}^{\circ}$ ' is a corrupt spelling of Josephus, then difficulties surround the previous word DMRY', which is normally a divine appellation, and one would expect to see DMRY used.

1. 4: MRY' M'(D)R. . ' the Lord [is my helper]'. The invocation for divine assistance is frequently encountered in both Greek and Syriac prayers and amulets, so that one can confidently claim that $M^{\prime}(D) R$ is a derivative of ' $D R$ 'help, assist '. ${ }^{47}$ Contextually either substantive, M'DRN' 'helper' or M'DRNWT' ' help, assistance ' would be fitting, although one may expect them to end in the 1st singular, pronominal suffix. On the other hand, if a Pael participle of ' $D R$ was used, then one could insert, before $L$ ', a plural substantive which would be the subject of 'BDYN which follows on 1. 5 .

1. 5: 'BDYN LY BYS' 'they will not do evil to me'. The present Peal participle of 'BD is given in the continuing, as well as, the momentary sense. ${ }^{48} \mathrm{It}$ clearly refers to a plural subject, which may be a substantive in 1.4 , or the verb

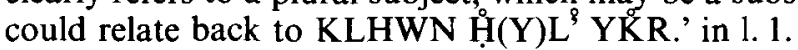

${ }^{42}$ R. Payne Smith, Thesaurus Syriacus (London, 1879-1901), vol. II, col. 1632.

43 ibid., col. 1609.

44 ibid., col. 1582.

${ }^{45}$ Littmann, op. cit., 21, in a discussion of the spelling of GYWRGYS by GYWRG'. Similarly, we find 'Stephanos' spelt in a variety of ways including 'STPN'. See Littmann, op. cit., 52.

${ }^{46}$ A. Caquot, 'Nouvelles inscriptions Araméenes de Hatra', Syria 29, 1952, 98, in discussion of the name HWBS'.

${ }^{47}$ W. Prentice, 'Magical formulae on Syrian lintels', American Journal of Archaeology, x, 1906, 145 , notes the frequency of $\beta$ o' $\theta \epsilon \iota$ or $\beta$ o' $\theta$ 7 rov on lintels in Syria. He also mentions the invocation of

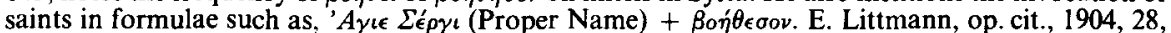
discusses an inscription from Bākirhā dated A.D. 546 which invokes for the salvation, L'WDRN', of the monks' souls. On p. 45 in an inscription from Mektebeh in A.D. 508-9 one reads, 'LH' 'L KL 'DRN BR BSS ' O God, (mighty) above all (?), helper of Bar Bassos'. On p. 46 Littmann claims that 'DRN is the Syriac equivalent of the Greek. H. Gollancz, The Book of Protection, being a collection of Syriac charms (1912, reprint London, 1967), makes numerous references to divine assistance in the individual amulets which have been translated.

${ }^{48}$ T. Nöldeke, Compendious Syriac grammar 1904, reprint Tel-Aviv, 1970, p. 211. 
Inscription $I^{49}$

1. 'N' 'SYR' BR GR ... R ...' ...

2. 'TN' D'S'L LS'(LM)K ...

3. D'S'L ȘLWTK S. . .

4. . . . Š ŠM' . . . . S(L)MT(?)

5. WHW PWM' ... T ...

6. S'LN ... SLMK KL ...

7. YS'L/NS'L ŠLMK MNK ...

8. Ș(LW) 'LY DM. . 'MYN

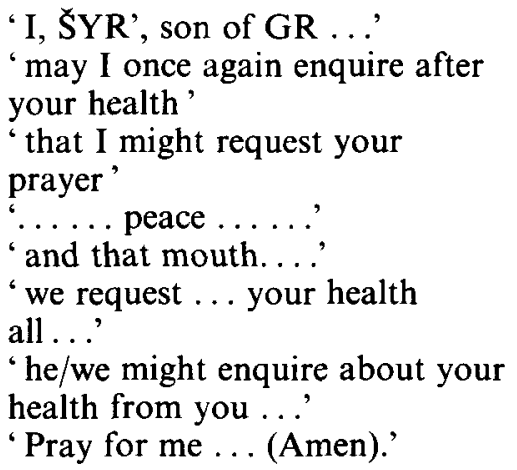

\section{Palaeographic notes}

1. 1: ' $N$ ' is read from the initial upright stroke which is unconnected to the second letter that is, in turn, ligatured to the final Alaph. The script appears to be Serta and whilst the degree of obliqueness of the two Alaphs is more exaggerated than elsewhere in the inscription, the letters are consistently written. The second letter is deciphered as a Nun from the short, upward projection. ${ }^{50}$

SYR' commences with a Shin. Whilst the smudges around this letter could suggest an open, triangular form akin to the Shin in the upper inscription, it would seem that the letter conforms with several later examples that are characterized by a prominent, upward, initial stroke that sweeps into a compact, inverted, filled triangle. The Shin seems to be joined to the following Yodh which is, in turn, ligatured to the Resh; a short, straight stroke that is clearly identified by the upper diacritical point. The final letter, in Serta style, is read as an unattached Alaph..$^{51}$

BR is distinguished by the initial, majuscule Beth and the Resh, which appears to reproduce the style of the example in the previous word. Indeed, the short, straight stroke is suggestive of a Zain, although the diacritical point clearly identifies the letter.

GR. . is read as a separate word from BR because of the spacing between the Gamal and the preceding Resh. ${ }^{52}$ The Gamal, in majuscule style, is ligatured to the following letter which is read as a Resh, from the traces of a short, straight stroke and a diacritical point. ${ }^{53}$

The remainder of the line is illegible except for a couple of sporadic letters.

1. 2: 'TN' shows a clear, cursive script where the initial, unattached Alaph is

${ }^{49}$ See plate III, IV $(b)$.

${ }^{50}$ Muraoka, op. cit., 86 , reads .TT. It is doubtful whether another letter occurs before the first legible character which is aligned with the right-hand, albeit crude, margin of the inscription. The interpretation of the initial character as a Taw probably stems from the faint foot which may be seen. However, in 1.2 Muraoka reads D'S'L where the unattached Alaph also has a foot. Unfortunately, the initial letter of 1.1 is too blurred to allow a definite assessment, but the reading .TT, being dependent on the presence of 'TT midway in the line, is tenuous since the latter is only speculative.

${ }_{51}$ This form of Alaph first appears in a Serta ms from A.D. 731, but is frequently attested after this date. It also occurs in both the Melkite and Nestorian scripts, being found in manuscripts from A.D. 1045 and A.D. 1259 respectively. See, Hatch, op. cit., plates XCV, CLXXXIV and CLXXIII.

${ }_{52}$ Muraoka, op. cit., 87, reads GR... as one word with BR.

${ }^{53}$ The majuscule style of Gamal appears in Serta manuscripts as early as A.D. 731 and dominates until the mid twelfth century when a cursive form emerged. See Hatch, op. cit, plates XCV-CXXV; CXXVI-CLIX. This transition does not seem to have taken place in the Nestorian or Melkite scripts. Similarly, inscriptions show the same conservative tendency wherein the majuscule style is preferred. 
written as a single, straight stroke. The Tau is distinguished by the downward projecting prongs of its foot. The penultimate letter Nun is ligatured to the final Alaph. Between the initial Alaph and the right-hand margin, if one can be established, is space for one character, but no trace appears. ${ }^{54}$

D'S'L commences with a letter that is interpreted as a Dalath, despite the absence of the diacritical point. It is noteworthy since, unlike the two examples of Resh in 1. 1, this character has a wedge-shaped head attached to a curved stem. The Dalath is separated from the following Alaph by a considerable space. The Alaph is unattached and unlike the examples in the preceding word, is distinguished by a short base line which leads into the curved, upward stroke and by a downward projecting prong at the junction of these two lines. ${ }^{55}$ The unusual spacing is once more repeated between the Alaph and the following Shin, which is introduced by an extremely long cursive stroke. The Shin is written clearly and is ligatured to the following Alaph whose form reproduces that of the previous Alaph. The final letter is read as an unattached Lamedh, although only its upward oblique stroke is clearly legible.

LS(LM)K begins with a faint Lamadh joined to a Shin whose form reproduces the style of the earlier example. The following Lamadh and Mem can only be conjectured, although it may be possible to see the upward oblique stroke of the latter. Likewise only traces of the final Kaph remain, but from these it appears that the letter accords with the earlier style as described by Hatch. ${ }^{56}$

The remainder of the line cannot be deciphered.

1. 3: D'S'L may be read, although the initial Dalath is badly smudged. The following Alaph appears to reproduce the form of D'S'L in 1. 2 and the Shin is introduced by a long, cursive stroke. Both the Alaph and the Lamadh are visible, but it seems that the Alaph is written in Serta style, thus consisting of a single, upward stroke.

ȘLWTK commences with a Șadhe whose tail serpentines in a roughly horizontal line and extends from the right rather than the left side as expected. ${ }^{57}$ Only faint traces of the following Lamadh occur, but these are sufficient to indicate that the letter is joined to the Waw that is distinguished by a semicircular shape. The unattached Taw is barely perceptible, but does appear to be Serta. The final Kaph is of the earlier style of the letter, although the junction of the downward and horizontal strokes seems to be more angular.

$\checkmark$. . . only the initial Shin of the third word may be read, as the line has become obliterated at this point.

1. 4: The illegible state of the inscription continues until the middle of this line.

SLM' where the initial Shin, which reproduces the form of the earlier examples, is ligatured to the following Lamadh; which is in turn joined to the Mim. This letter is read on the grounds that both the 'bowl' and the upward oblique stroke of the letter may be discerned. ${ }^{58}$ The final letter appears to be an

${ }_{55}^{54}$ Muroaka, op. cit., 86, proposes that two letters precede the initial Alaph.

${ }^{55}$ The usage of the two types of Alaph occurs in an inscription from Dēr Sim'ān. Littmann, op. cit. (1904),29, says that " the initial Alaph is only a perpendicular stroke, whereas the final Alaph has kept its old form'. We would specify that the designated 'old form' is the semi-majuscule Alaph. Ibid., Inscription 46, indicates that this form did appear in the initial position.

${ }^{36}$ Hatch, op. cit., 38, notes that, "the earlier form of the letter was also employed in the Serta style of writing until the second quarter of the twelfth century and occasionally thereafter.' This form of final Kaph is distinguished by a serpentine leading into the straight downward stroke.

${ }^{57}$ This Sadhe is unique and one may ask whether its form has resulted from difficulty of writing on the friable limestone medium.

${ }_{58}$ Muraoka, op. cit., 88, has read a Heth but otherwise does not comment. 
Plate I

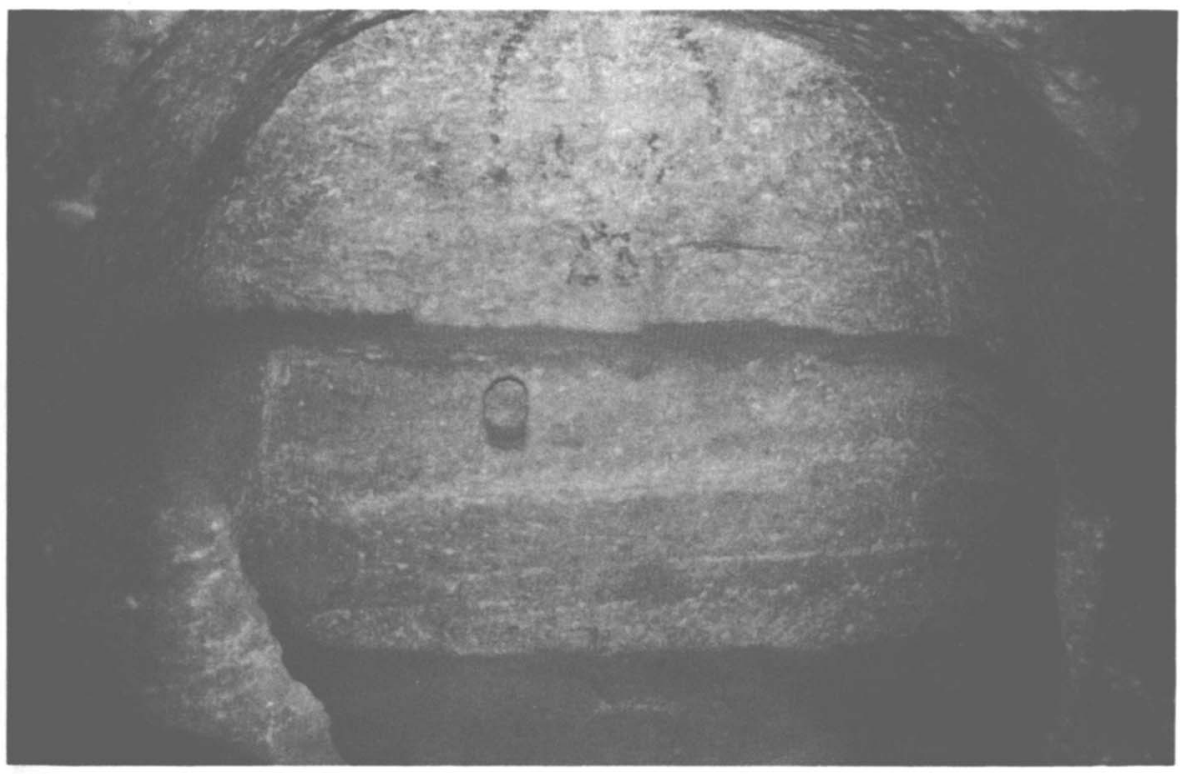

(a) Djebel Khaled. The tomb-chamber showing the bas-relief 'Maltese-type' cross set in a (red) painted wreath.

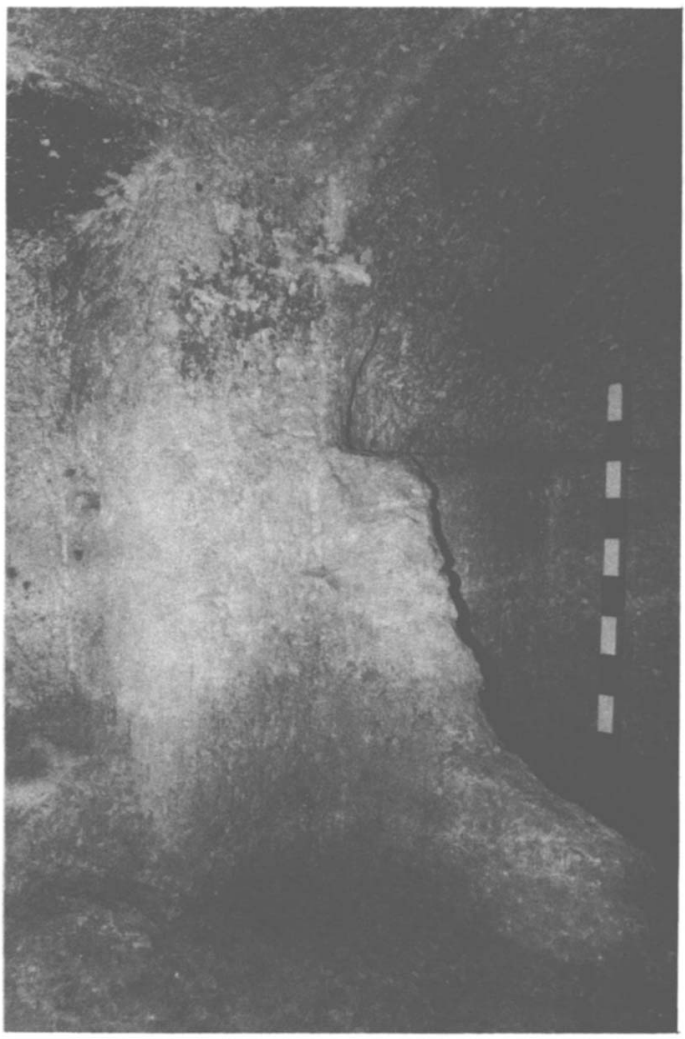

(b) The lower left-hand side of the arch showing Inscriptions I and II in situ. 
Plate II

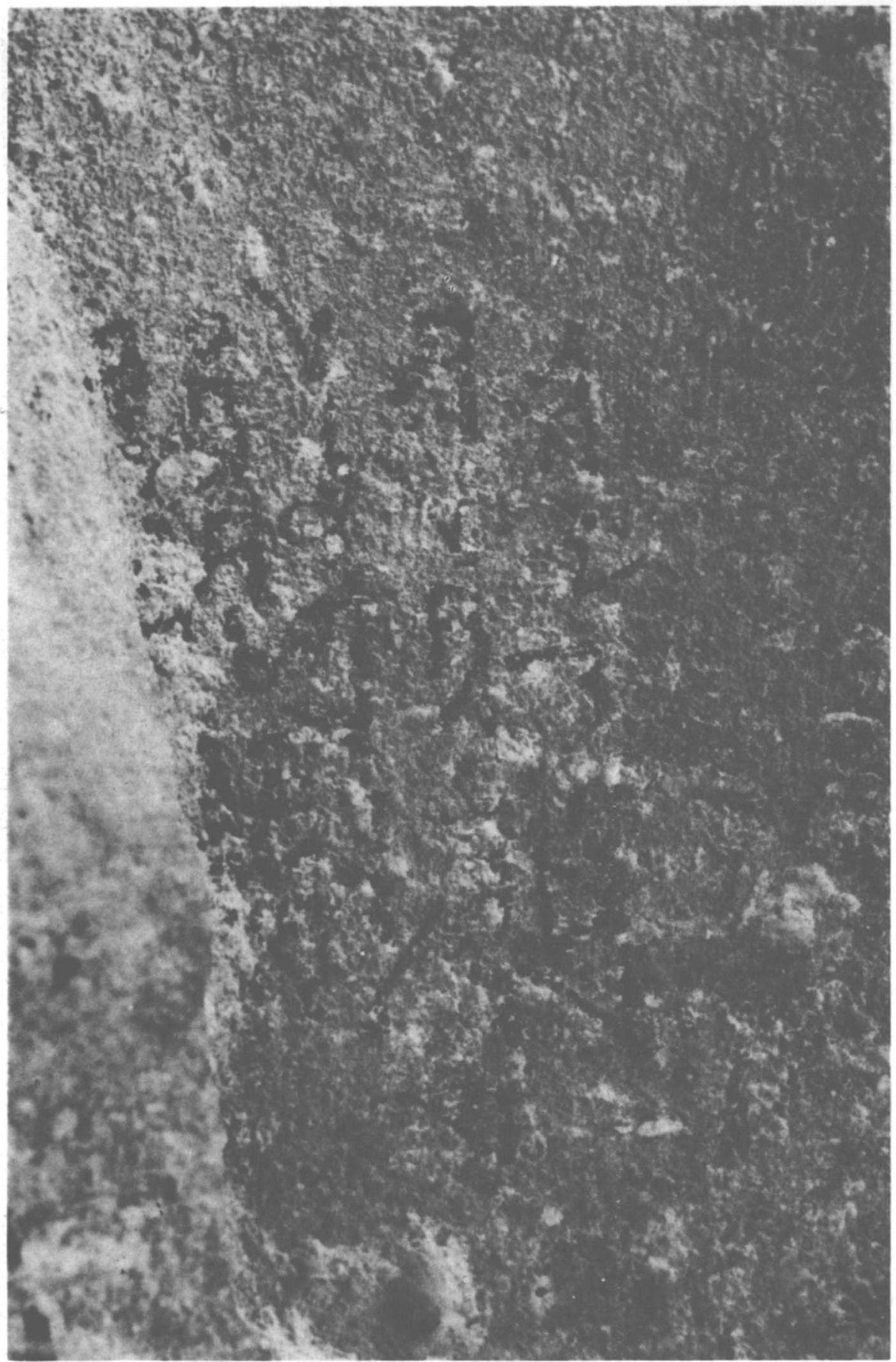

Inscription I 
Plate III

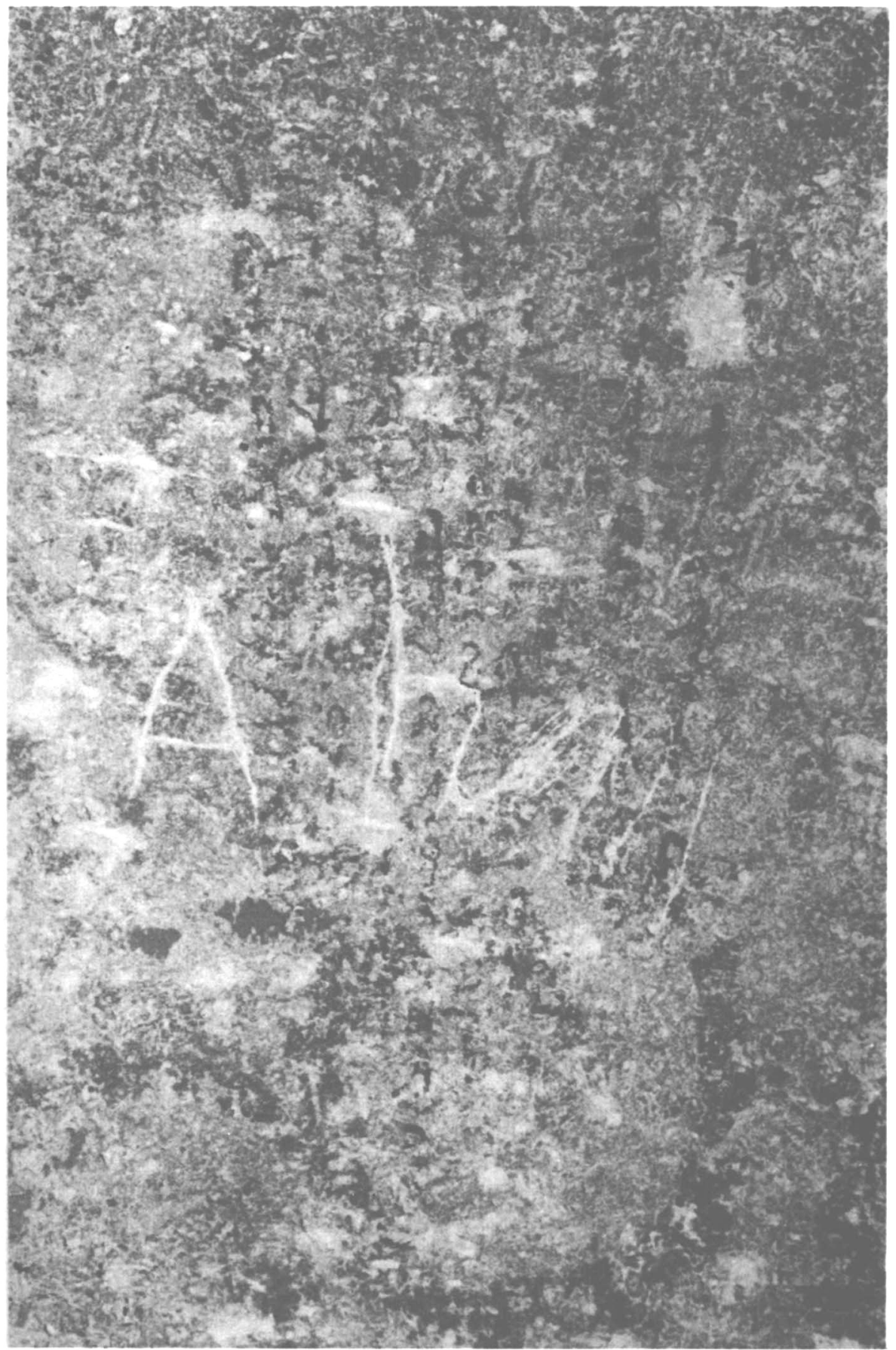

\section{Inscription II}




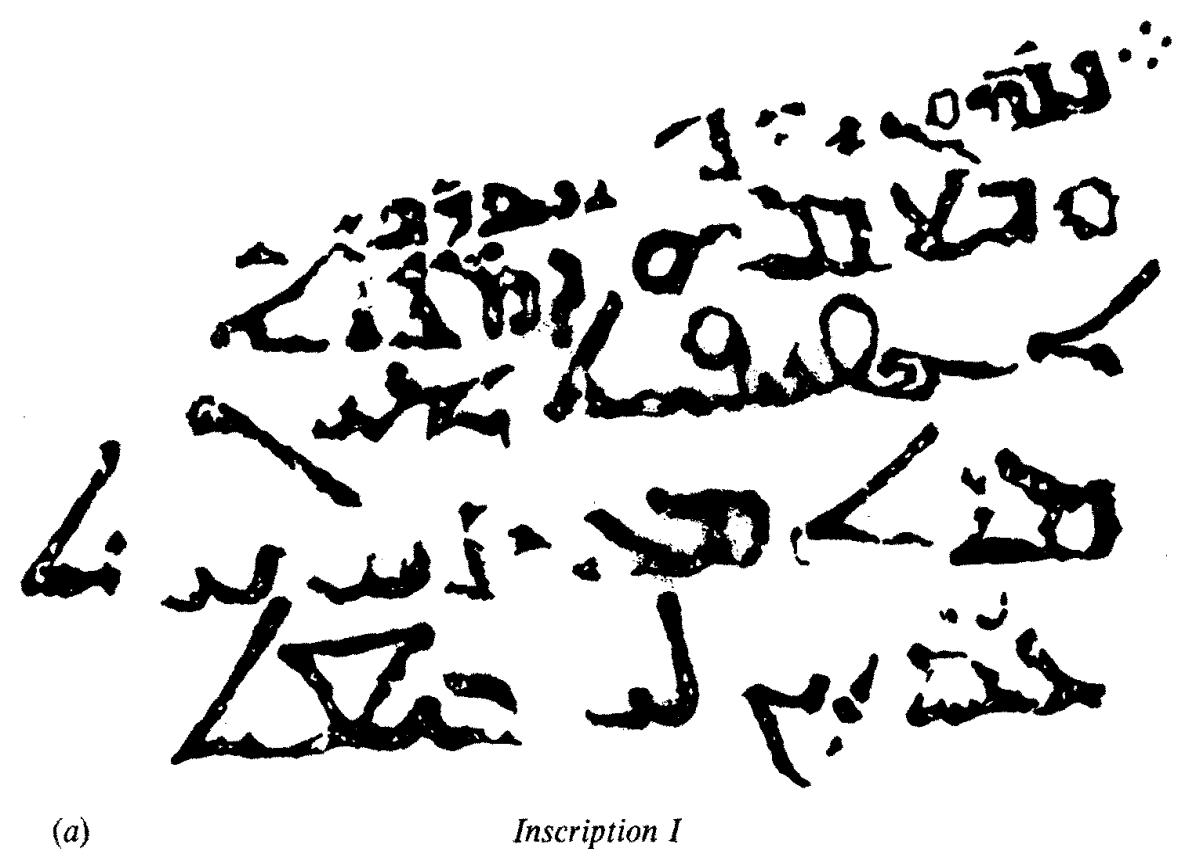

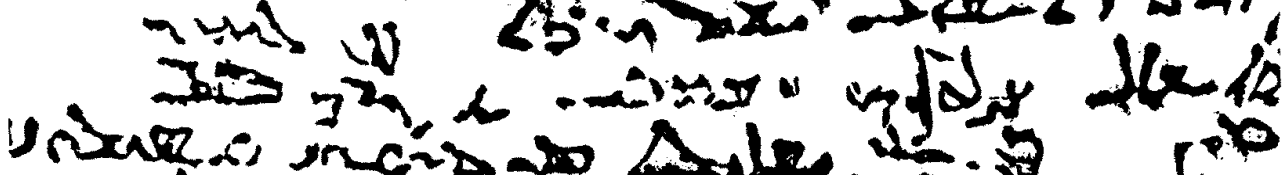

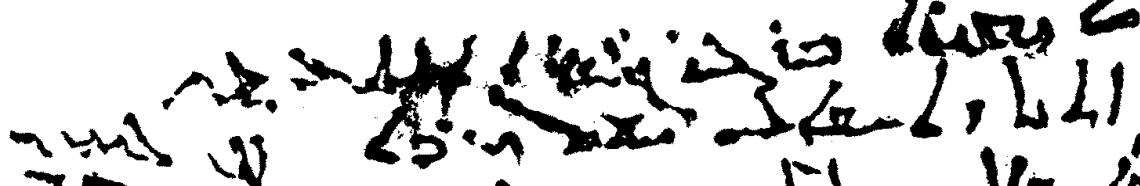
und: 4 कीजिएक

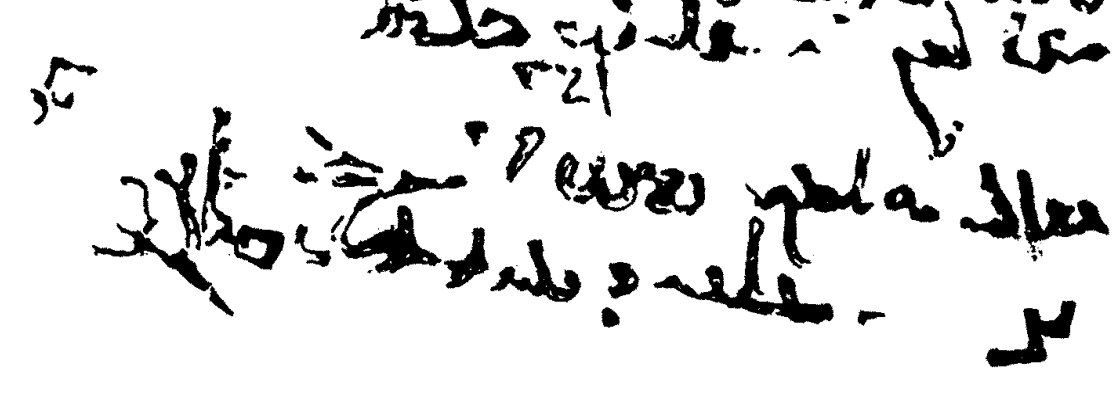

(b)

Inscription II 
Alaph since it has a downward projecting prong at the junction of the base and upper lines. ${ }^{59}$

S(L)MT(?) is read at the end of the line. Whilst the triangular form of the initial Shin is visible, the following Lamadh can only be postulated. The third letter, Mim, is distinguished by its elongated upper oblique stroke. ${ }^{60}$ An upward connecting stroke leading from the Mim to the fourth letter identifies it as a Taw. At this point the word might conclude, or there might be a final letteralthough the black smudge could even be the initial character of a new word. ${ }^{61}$

1. 5: WHW begins with an 'open' Waw, in contrast to the second Waw which is closed. ${ }^{62}$ The second letter, which has been interpreted as $\mathrm{He}$, is enigmatic in that its form neither conforms to the majuscule or minuscule types. Whilst the letter displays the open, square form of the Estrangela He, there is no division of the letter as would be customarily expected. ${ }^{63}$ A clearly legible Serta Waw concludes.

PWM' begins with a Pe that is notable for its slightly flattened head. The second letter, which is ligatured to the Pe, is tentatively read as a Waw since the initial curvature of the character would support such an interpretation. However, because of the problem of insufficient space before the penultimate letter, the shape of the character-being a short, upward stroke--may suggest either a Resh or a Dalath. ${ }^{64}$ The word concludes with a cursive Alaph, but the preceding letter to which it is ligatured is not entirely legible. From the traces of the bowl of the letter and the oblique, upward stroke it is read as a Mim.

The remainder of the line cannot be deciphered.

1.6: S'LN begins with the long introductory stroke of the Shin, albeit somewhat smudged. However, the triangular body of the letter may be discerned as well as the ligature to the following Alaph. ${ }^{65}$ This letter is written in the Serta style of a single, upward stroke that has a slight rightward slant. ${ }^{66}$ Between the Alaph and the next letter is an abnormal spacing, suggesting the possibility of two words instead of the one which I have read. This possibility is particularly attractive, irrespective of whether the word is interpreted as either MN or LN. I have selected the latter reading from the traces of an upward stroke ${ }^{67}$ and on the basis of the repetitive usage of $S^{\prime} L$ throughout the inscription, I have read the four letters as one word.

SLMK is only faintly legible, but the triangular body of the Shin may be

${ }^{59}$ idem discerns a Taw, possibly on the basis of the line, which I have interpreted as an extended, oblique upper stroke of Mim, being the ligature from the letter Heth to the Taw. But this interpretation also ignores the clear base line between the penultimate and final characters.

${ }^{60}$ This elongated stroke would lend support to the earlier reading of the penultimate letter of SLM' as Mim.

${ }^{61}$ If it did form the final letter of $S(L) M T(?)$, then we could expect to read either a He or an Alaph.

${ }^{2}$ idem reads the letter as a $\mathrm{He}$, but the initial upward stroke would have to be supplied even if it was of the 'open' form. On the other hand, the combination of open and closed forms of Waw occurring in the same inscription can be seen in an example, dated to the twelfth to thirteenth century A.D., from the Convent of St. Behnam near Nimrud. See Pognon, op. cit., Inscription 75.

${ }^{63}$ Muraoka, op. cit., 88, postulates that the letter could be either a Qoph or a 'clumsily formed ' Waw. He questions the first reading on the grounds of the letter's angularity and it is for this reason that we reject the second suggestion. The contiguity of the closed He with the following letter as seen in a Serta MS dating from A.D. 902, may suggest that the character was a closed He wherein the lefthand loop has largely deteriorated. See Hatch, op. cit., Plate CXIII.

${ }^{64}$ This interpretation by Muraoka, op. cit., 86, may be accepted on purely palaeographical grounds, whereas his alternate suggestion of a Yodh or a Nun seems to be most unlikely.

${ }^{65}$ idem reads the initial letter as a Nun, on the basis of the short, upright stroke which we have interpreted as part of the triangular body of the Shin.

${ }^{66}$ The slant of the Alaph reproduces that of $D^{\prime} S^{\prime} L$ in 1.3 , but it may be noted that the slant of the Alaph in N/YS'L in 1.7 is leftward, thus showing the inconsistency of the scribe's hand.

${ }^{67} \mathrm{idem}$ reads N'MN, thus interpreting the third letter as a Mim; probably from the small circle which may be seen at the junction between the upright and the base strokes. 
detected as well as the upright stroke of the Lamadh. ${ }^{68}$ This letter is ligatured to the following Mim, so read from the oblique, upward stroke. ${ }^{69}$ If the third character is ambiguous, the final Kaph is written clearly in the earlier style as described by Hatch.

KL commences with a Serta Kaph that is ligatured to the following Lamadh. $^{\text {70 }}$

1. 7: NŠ'L or YS'L since the short, upright stroke of the first letter could indicate either a Yodh or a Nun. The remaining letters, namely, Shin, Alaph and Lamadh, are legible.

SLMK begins with a blurred Shin, but the Lamadh, Mim and Kaph are clear and the penultimate letter provides a clear example of a Serta Mem.

MNمK is tentatively suggested since the inscription has become very deteriorated at this point. A Mim is conjectured from the bowl-like shape and the traces of an upward, oblique stroke. If it is a Mim, then it may be noted that it would be considerably larger than the examples which have been previously encountered. Traces of an upright stroke may indicate a Nun and the serpentine shape of final Kaph can just be detected.

At this point the line has become illegible.

1. 8: S(LW) commences with a distinct Șadhe, in contrast to the remainder of the word which has been largely obliterated except for the vestiges of a horizontal line that may indicate a final Yodh. ${ }^{71}$ But restoration of LamadhWaw would be feasible; both semantically and on consideration of spacing.

' $L Y$ provides an excellent indication of the spatial requirements of the combination Lamadh-Yodh, as all the letters of this word are legible.

DM ... shows a Dalath cursively written, as compared to the previous examples of this letter. The Mim is suggested from the upward, oblique stroke and the bowl; albeit incomplete. The rest of the word has deteriorated beyond reconstruction. ${ }^{72}$

${ }^{9} \mathrm{M} Y \mathrm{O}^{\circ}$ may be suggested from the traces of the upright stroke of an Alaph, the bowl of the Mim and the possible downward stroke of a final Nun. However, this interpretation remains conjectural.

\section{Palaeographic summary}

The seriously deteriorated state of Inscription $I I$ has presented considerable palaeographic difficulties, which have been compounded by the absence of many letters - including Heth, Teth, Semkath and Qoph. However, as a counterbalance to this deficiency, many of the characters occur several times in the inscription. The repetitive usage of Alaph, Shin, Lamadh and final Kaph is particularly informative for our understanding of the inscription's palaeographic development. Firstly, they reveal that the scribe's hand was, within the bounds of the medium, consistent since the chirographic variation which was noticeable in Inscription I is almost absent.

A notable exception occurs in the presence of two different styles of Alaph. By far the dominant stream is represented by the single, upright stroke of the minuscule character. But, on 1.2, we also find two clear examples of a semimajuscule type that is distinguished by the foot at the junction of the base and

${ }^{68}$ idem reads the Lamadh as an Alaph.

${ }^{69}$ idem reads the Mim as a Lamadh.

${ }^{70}$ idem reads the Kaph as a Beth.

71 idem reads NS. ..., thus interpreting the initial stroke as a Nun, whereas it is, in my opinion, part of the Sadhe. This form of the letter occurs in Serta manuscripts until the mid twelfth century when there appears to have been a 90 degree shift in the initial stroke to produce the subsequent " 3 ", form. See Hatch, op. cit., Plates CXXIV and CXXVI.

72 idem reads DMY. 
upper lines, as well as by the slant of the latter. Whilst the deterioration of Inscription II does prevent any conclusive results from being obtained, it would seem that the occurrence of the semi-majuscule type is restricted to the first two lines, where it is interspersed amongst the minuscule Alaph.

Both styles of Alaph are accommodated within the Serta tradition in which Inscription II can be placed. The letters Waw and Mim have the closed, rounded forms of this script and the letter Taw is also of the Serta type. Several of the characters, particularly the Sadhe and the final Kaph appear to belong to the early stage of the script; to the period between the eighth and eleven/twelfth century A.D. ${ }^{73}$ Similarly, the letters Gamal and Shin are written in a majuscule style, in contrast to the cursive forms which became the norm of Serta after the eleventh-twelfth century A.D. ${ }^{74}$ These palaeographic traits suggest that Inscription II may be dated likewise to the period between the eighth and eleventh/ twelfth century.

However, in the Melkite tradition the changes, which took place in the Serta script in the eleventh to twelfth centuries A.D., were not reflected. Hence the earlier forms of Sadhe and final Kaph were retained, along with the usage of the majuscule type Shin and Gamal. ${ }^{75}$ Similarly, the two forms of Alaph and Taw, with its two downward prongs, are found in the Melkite script. The presence of these features in Inscription II may lead us to consider that it is Melkite. If this is so, then the dating given above, of eighth-eleventh/twelfth century A.D., would not be necessarily applicable and the inscription could emanate from after the twelfth century A.D.

\section{Commentary}

1. 1: 'N' SYR' BR GR ... 'I, SYYR', son of GR. . . 'N' . . BR is an opening formula that is commonly encountered in inscriptions and introduces the author of the deeds which are subsequently related. Hence SYR' would appear to be a proper name, although it is also known as a title of a convent which, according to Bar Hebraeus, was situated on the banks of the Euphrates. ${ }^{76} \mathrm{GR}$ $\ldots$ is incomplete, but it is probably a proper name. ${ }^{77}$

1. 2: 'TN' D'S'L LS(LM)K 'may I once again enquire after your health'. 'TN' ' once again' expresses a wish or a request by the $1 \mathrm{sg}$. Imperfect Peal of $\mathrm{TN}^{\prime}{ }^{78}$ It is tempting to prefix a Dalath, thereby commencing a relative clause, but the following Dalath would make the construction awkward. D'S'L

${ }^{73}$ Hatch, op. cit., 46, divides the history of the Serta script into two major periods; the first from A.D. 700 to A.D. 1100 and the second from A.D. 1100 until the sixteenth century. On p. 38 , in his comments on the final Kaph, Hatch notes that, "the earlier form of the letter was employed in the Serta style of writing until the second quarter of the twelfth century and occasionally thereafter. The later form of final appeared in the second quarter of the twelfth century and continued in use down to the end of the sixteenth century.' In the same period the Sadhe appears to have undergone a reorientation, for the letter was written as 3 rather than as $\$$, as occurs in earlier manuscripts. See Hatch, op. cit., plates XCVII, CXXIV and plates CXXVI, CXXXVI.

${ }_{74}$ ibid., 36, notes that Shin was written in the Estrangela fashion in the oldest Serta manuscripts, being those up to the last quarter of the eleventh century A.D. when the cursive style appeared and superseded the majuscule Shin. The same phenomenon seems to have occurred with the letter Gamal, where a cursive style appeared in the middle of the eleventh century and replaced the Estrangela style Gamal that was previously used in Serta manuscripts. See Hatch, op. cit., plates XCVII-CXXV and plates CXXVI-CXXXVI.

${ }^{75}$ idem, plates CLXXXIV-CXCVII, although on p. 29 Hatch cautions that Melkite manuscripts are not well represented, with a paucity of dated manuscripts prior to the sixteenth century.

${ }^{76}$ Payne Smith, op. cit., col. 4143, notes under the entry SYR', Shira; 'nomen coenobii Turabdinensis ad ripas Euphratis 'as quoted by Bar Hebraeus. If SYR' is a title, then the inscription could commence with a statement of rank before the proper noun. See Littmann; op. cit., Inscriptions $15,42-4,62$, for examples which commence with the formula: 'I' + title + name.

${ }^{77}$ If $\mathrm{SYR}$ ' is interpreted as a title, then BRGR could be read as a single word as Muraoka has done.

${ }^{78}$ Nöldeke, op. cit., $\$ 266$, p. 208. 
LS(LM)K 'enquire after you' or perhaps more formally 'greet/salute you'. The Lamadh prefixed to SLMK presumably indicates the direct object. ${ }^{79}$

1. 3: D'S'L ȘLWTK ' that I might request your prayer'. Here no Lamadh identifies the direct object of S'L 1 sg. Imperfect Peal.

1. 4: ... ŠLM' ... S S(L)MT(?) '. . peace ... ŠLM' can be read either as a masculine singular adjective 'perfect/complete/full' or as a masculine singular noun ' peace/health/welfare', or as an active participle feminine Peal of SLM ' is finished/is concluded '. It is difficult to know which option to apply, but it is tempting to adopt the last, since ȘLWTK 'your prayer' is a feminine substantive.

1. 5: WHW PWM' 'and that mouth'. A singular, masculine demonstrative pronoun is a fitting accompaniment to the singular, masculine substantive. Despite the illegibility of a large proportion of the inscription, the phrase would be contextually fitting with the repeated usage of $\breve{S}^{\prime} L$.

1. 6: S'LN ... ŠLMK KL' we request ... your health all'. The poor state of the inscription does not allow us to determine why the Perfect tense has been used, when the Imperfect tense has been preferred elsewhere.

1. 7: YS'L/NS'L ŚLMK MNํํำ he/we might enquire about your health from you'. A variant on the above combinations of S'L + SLMK in that either 1 plural or 3 masculine singular person has been used. On the basis of the 1 singular person that occurs in ll. 2 and 3 the reading NS'L might be adopted.

1. 8: S(LW) 'LY DM ... 'MYN 'pray for me ... (Amen)'. The request for prayer, or variations thereupon, often concludes an inscription, although the Imperfect tense occurs more frequently than the Imperative ${ }^{80}$ It is tempting to reconstruct the latter part of 1.7 as $\mathrm{KL} \mathrm{DQR'} \mathrm{'} \mathrm{everyone} \mathrm{who} \mathrm{reads} \mathrm{'} \mathrm{since} \mathrm{this}$ clause is frequently combined with the request for prayer expressed in the Imperfect tense. ${ }^{81}$ However, the palaeographic reading on 1.8 supports the use of the Imperative of ȘL. The faintly discernible 'MYN at the end of 1.8 is an appropriate conclusion to the inscription.

\section{Inscriptions $I$ and II: functions and context}

In his description and discussion of the Roman tomb-chamber at Djebel Khaled, Clarke has suggested that the graffiti on the wall outside the sepulchre, 'crosses by themselves or enclosed within circles, triangles', indicate its re-use for a later Christian burial. ${ }^{82} \mathrm{He}$ also cites the presence of the two Syriac inscriptions to signify that the Christian occupant of the grave was of an exalted status and was regarded as 'saintly ${ }^{83} \mathrm{He}$ paints a vivid picture of the ascetic trends in northern Syria during the fourth century A.D., implying that this was the type of likely context in which the two inscriptions were written.

The palaeographic studies indicate that both Inscriptions $I$ and $I I$ have emanated from a much later period, since the earliest date that can be proposed is the eighth century A.D., for Inscription II. Of course, this inscription may be contemporary with Inscription I which appears to have been written only in the twelfth century A.D. Indeed, the presence of Inscriptions $I$ and $I I$ at Djebel Khaled may imply a Christian tradition spanning several centuries. And,

\footnotetext{
${ }^{79}$ See the comments by Muraoka, op. cit., 87-8, regarding the idiosyncrasy of this construction.

${ }^{80}$ See Littmann, op. cit., Inscription 8 and Pognon, op. cit., Inscriptions 95, 102 and 103 for examples of the plural Imperative. By contrast, the Imperfect construction occurs in Littmann, op. cit., Inscription 62 and Pognon, op. cit., Inscriptions 24, 26, 54, 67, 68, 75, 92 and 94. Littmann, op. cit. (1934), 20 comments on variants of the formula.

${ }^{81}$ See Littmann, op. cit., Inscription 62 and Inscriptions 24, 26, 54, 67, 68, 75, 92 and 94 in Pognon, op. cit.

${ }_{82}$ Clarke, op. cit., 79.

83 idem.
} 
together with the graffiti, both inscriptions may distinguish the tomb-chamber as a sanctuary within a monastic complex that existed at this site.

Whilst the Roman tomb-chamber was re-used for a Christian burial, the presence of ' fragments of nondescript coarse buff-ware with some sherds of the ubiquitous red-slip ... and a few fragments of glass' suggests some occupation, possibly sporadic. ${ }^{84}$ Since Djebel Khaled was close to Qal'ah Najm which was, particularly during the medieval period, the most important crossing point of the Euphrates in the north Syrian region, the sepulchre may have been a makeshift caravanserai for traders. ${ }^{85}$ In such circumstances, Inscription II could have been a message left after a party failed to keep a rendezvous. ${ }^{86}$

Alternatively, Inscription $I I$ could have been written by pilgrims. That they visited the area is well attested and as early as A.D. 386 Egeria stayed at Hierapolis for a day before crossing the Euphrates at a point fifteen miles from this city ${ }^{87}$ From A.D. $6 \mathrm{C}$, when Hierapolis became one of the great centres of Christianity in northern Syria, the volume of pilgrims traversing the Euphrates can be expected to have increased considerably ${ }^{88}$ The many crosses incised into the wall leading to the tomb-chamber's entrance intimates that not a few also visited Djebel Khaled.

If the site was on the pilgrim route between Hierapolis and Mesopotamia, a monastery may have existed there. ${ }^{89}$ An integral feature may have been the set of three rooms that were directly above the sepulchre, which may have been a primitive church. ${ }^{90}$ Hence Inscription II may have been written by a guardian or custodian of the tomb-chamber who was responsible for its maintenance. ${ }^{91}$ But the writer, if he was a member of the monastic community, was not a deacon or

${ }^{84} \mathrm{idem}$. The pieces of pottery and glass are presumed to be contemporary with the early site, although intermittent occupation may have continued even up to modern times. A graphic account of the type of habitation is given by G. L. Bell, Amurath to Amurath (London, 1924), 39. When in the area of Qal'ah Najm she " rode from the Euphrates up a bare valley ... to a great cave inhabited by Arabs. It contained three chambers, the opening of which had been fenced in by the latest inhabitants with screens made of rushes.'

${ }^{85}$ G. Goossens, Hierapolis de Syrie: Essai de monographie historique (Louvain, 1943), 195-9 discusses the crossing points of the Euphrates and, in particular, Qal'ah Najm. In addition to the overland traffic between Seleucia and Antioch, river trade may also have occurred especially since the situation of Djebel Khaled, 'on the south side of a range of hills through which the Euphrates forces a swift passage', has been described as a 'suitable starting point for the navigation of the lower river'. See R. P. Harper, 'Excavations at Dibsi Faraj, Northern Syria 1972-1974. A preliminary note on the site and its monuments', Dumbarton Oaks Papers, 29, 1975, p. 321, n. 4.

${ }^{86}$ Muraoka, op. cit., 87.

${ }^{87} \mathrm{~J}$. Wilkinson, Egeria's travels to the Holy Land (Jerusalem, 1981), 113. She only provides scant, general details in her description of Hierapolis as a city of 'great plenty, rich and very beautiful'. Nor does she supply any further information about the crossing point on the Euphrates which, from the distance quoted, could be Qal'ah Najm. Presumably, Christian traditions associated with both Hierapolis and the hinterland had not evolved, for we can expect that they would have been recorded by Egeria.

${ }^{88}$ Goossens, op. cit., 175 , notes that the patron saints of Hierapolis were Peter and Paul. By the sixth century A.D. the city boasted a church dedicated to St. Peter and also the reputed tomb of St. Matthew. However the greatest fame of Hierapolis derived from St. Simeon Stylites whose feats attracted thousands of pilgrims.

${ }^{89}$ P. Kawerau, Die jakobitische Kirche im Zeitalter des syrischen Renaissance (Berlin, 1960), 43, notes the components and the distinguishing features of monastic lay-out. Several aspects of the Roman station at Djebel Khaled would support its adaptation to a monastery, not least its location on precipitous cliffs. The walls would also have provided protection and the water cisterns in the acropolis area would have supplied the community's needs. The burial chambers could have served as cells for the monks and also provided hospice facilities as well as being converted into a church.

${ }_{90}$ Clarke, op. cit., 80. The central role of a chapel in a monastic complex is highlighted by $\mathrm{E}$. Sachau, 'Edessenische Inschriften', Zeitschrift der Deutschen Morgenländischen Gesellschaft, XXXVI, 1882, 151. In his discussion of the ruins of Dēr Ja'kūb, near Edessa, he says, "wenn das Gebäude ein Kloster gewesen wäre, so müsste man eine Capelle nachweisen können '.

${ }_{91}$ T. Canaan, Mohammedan saints and sanctuaries in Palestine (Facs. ed. Jerusalem), 17, specifies that in large shrines which were visited by many pilgrims, 'a servant lives all the year around in such a sanctuary to guard it '. 
a priest for, as Littmann says, ' he certainly would not have forgone the pleasure of adding his title to his name' ${ }^{92}$

The introductory formula: 'N' SYYR' BR GR 'I am Shira son of GR...' designates the writer's name and part of his patronym, but provides no further information. Nor does the inscription identify the dedicant, although the use of .TN' ' once again' in 1.2 suggests that the writer was renewing his acquaintance. Furthermore, the salutation D'S'L LŚLMK 'I greet you' or, 'I enquire about your well-being' which is repeated throughout the inscription imparts a familiarity, albeit polite. The tenor is continued in 1.3, D'S'L SLWTK 'I request your prayer'.

Whilst the deteriorated condition of Inscription II severely curtails knowledge of its contents, it would appear that the writer sought approval for deeds which he had done. These may have been restoration works in the tombchamber since the final line-SLW LY. . 'MYN' Pray for me ... Amen'-uses a formula that concludes inscriptions commemorating the erection of churches, or the restoration of parts thereof. ${ }^{93}$ Such activities would suggest that the sepulchre was a sanctuary, or a holy place, perhaps dedicated to a saint who was its esteemed occupant.

Whereas Inscription II may record the restoration of a shrine at Djebel Khaled, the contents of Inscription I immediately place it into a different category. Muraoka has proposed that it is an execration text, presumably directed against the unspecified subject of 11.4-5, L' 'BDYN LY BYS' ' they will not do evil to me', from which the author hoped to gain immunity. ${ }^{94}$ The prophylactic tenor of the inscription indicates that it is an invocation against evil. L. 1, KLHWN ${ }^{\mathrm{H}}(\mathrm{Y}) \mathrm{L}^{\S} \mathrm{YK}$ R.' ' all those .. . powers ' may be the title of the text, naming the forces from whom one was to be protected. ${ }^{95}$

Like the numerous Greek $\beta o \eta^{\prime} \theta_{\iota}$ inscriptions found in northern Syria, Inscription I calls for assistance. ${ }^{96}$ Ll. 3-4, 'WN MRY' $\mathrm{M}^{\prime}(\mathrm{D}) \mathrm{R}$... ' Oh, the Lord (helps) ', is coupled with ll. 4-5, L' 'BDYN LY BYS'' ' they will not do evil to me ', to propose a successful result. Here the use of MRY' 'Lord' reiterates the authority cited in 1.2, WBSMH DMRY' 'SYY' ' in the name of the Lord '.SYYP' '. This typical introduction to incantations is enigmatic for, '.SYYP' may be an epithet qualifying DMRY'. Alternatively, despite the problems surrounding DMRY', 'SYP' may be the name of a saint-possibly even the one to whom the sanctuary was dedicated.

Inscription I may have requested aid in the face of the Mongol terror that arose in the thirteenth century A.D. when Hulugu Khan and his hordes swept through northern Syria, murdering and pillaging. Bar Hebraeus chronicles that, 'a great slaughter took place in the city of Mabbugh (Manbij) and troops ...

92 Littmann, op. cit. (1904), p. 39

${ }^{93}$ Pognon, op. cit., Inscriptions 62, 75, 92, 94 and 96 which record restoration works ranging from an entire church (Inscriptions 62,96), to an altar (Inscription 75), a door (Inscription 92) and a tower (Inscription 94). Littmann, op. cit., Inscription 62 dating from the fifth to sixth centuries A.D., which occurred on the lintel of the church at Shekh Sleman in northern Syria offers a variant by recording:

'I, the deacon Euthalios, wrought this.

May everyone that reads (this) pray for me.'

Presumably some restoration works did take place, although they are not specified. Whilst the executor identifies himself, the process which he adopts differs from Pognon, op. cit., Inscriptions $62,75,94$ and 96 where the names are narrated in the third person after the works are detailed. As such, the inscription from Shekh Sleman appears to be a combination of the opening and closing formulae that occur in Inscription $I$, perhaps representing the genre in a compressed form.

${ }_{94}$ Muraoka, op. cit., 86

${ }^{95}$ See Gollancz, op. cit., where numerous amulets are headed by a summary of the evils with which one is to contend.

${ }_{96}^{6}$ Ref. n. 47. 
fighting men were posted ... against the fortress of Kal'ah Najm ... and all the people ... were killed '.97 It is not inconceivable that these activities were extended to Djebel Khaled and in such circumstances, 1. 1, KLHWN H(Y)L' YKR.' 'All those ... powers ', may refer to the troops of Hulugu Khan, rather than spiritual forces.

The position of Inscription $I$ at the extreme edge of the vaulted arch of the sepulchre suggests that it had a preventative function. Over and beyond the protection which was afforded by the site's physical location, the sanctity of the sanctuary may have been considered to be more potent in the curbing of excesses. ${ }^{98}$ The writer of the inscription may, therefore, have taken refuge in the tomb-chamber in the hope of not being discovered, or at least of being spared. ${ }^{99}$ His selection of the tomb-chamber may imply that it was the focal point of the monastery which had been established at Djebel Khaled: a mortuary chapel dedicated to the founder. Or, the tomb-chamber may have housed the relics of an anchorite or a holy man from whose traditional association with the site a later institution evolved.

As the graffiti attest, the sanctuary may have been visited by pilgrims who were travelling to Hierapolis, which had become a popular centre of Christianity after the sixth century A.D. Whilst the identity of the saint still remains shrouded in mystery, the palaeography of the inscriptions suggests that the monastery may have been Melkite. Indeed, the north Syrian region, between Aleppo and the Euphrates was an area of Melkite dominance up to the medieval period. That the monastery at Djebel Khaled was part of this pattern seems probable, but its identification and history remain, at present, enigmaticawaiting further exploration.

${ }^{97}$ E. A. W. Budge, The Chronography of Gregory Abu'l Faraj (Oxford, 1932) 435.

${ }_{98}$ Pognon, op. cit., Inscription 74 relates the charming tale of the instant conversion of the pillaging Tatars (Mongols) who came upon the bones of a saint upon their arrival at the monastery and were pacified. Doubtless, the writer of Inscription I may have hoped for the same spirit to prevail, should such a situation arise.

${ }_{99}$ See Budge, op. cit., 420 , which narrates that an old man and his son, in the face of the Tatars' (Mongols') arrival at Margā, 'did not wish to flee to the monastery with the rest of the people of that village, but he climbed the mountain on the other side, and he went and hid in a strong and rocky place on the banks of the Euphrates.' This must have been a common reaction. 